\title{
THE DIRECT AND INDIRECT \\ BENEFITS OF WHANAU \\ CONNECTIONS FOR MAORI \\ EMPLOYEES: TOWARDS \\ SATISFACTION \& MENTAL HEALTH OUTCOMES
}

\section{Jarrod M Haar \& Maree Roche}

\author{
University of Waikato \& Waikato Institute \\ of Technology
}

\begin{abstract}
For Maori, the indigenous people of New Zealand, whanau (extended family) is of fundamental importance and the present study tests whether working with whanau has positive effects for Maori employees. Using a sample of 197 Maori, workplace relationships amongst Maori employees and their whanau were tested. Factor analysis found two distinct dimensions: whanau work connections and whanau home connections, which represented interactions in the workplace about work and home respectively. These were explored towards satisfaction and mental health outcomes. Due to the importance of whanau for Maori, we hypothesized that greater whanau connections would have a beneficial influence on outcomes. Findings showed that whanau work connections significantly and positively influenced job satisfaction and workplace cultural satisfaction, while whanau home connections significantly and negatively influenced anxiety and depression. In addition, moderation effects were found between the two dimensions of whanau connections towards all outcomes. Overall, higher whanau connections on both dimensions were advantageous. The findings indicate that indigenous employees may respond with the strongest positive outcomes when interacting and working with their extended family, which has previously been unexplored.
\end{abstract}

\section{Introduction}

In the quest to better understand and enhance positive wellbeing in the workplace, organizational researchers have drawn on the principals, research and theoretical developments in positive psychology (Wright \& Quick, 2009). In terms of understanding positive workplace wellbeing, positive organizational scholarship (POS) is defined as "concerned primarily with the study of positive outcomes, processes, and attributes of organizations and their members" (Wright \& Quick 2009, p. 148). While positive psychology expands and intensifies its theoretical and research base, and the implications of psychological, social and cultural contexts of wellbeing (Csikszentimihaly, 2009), POB seeks to understand how enhancing workplace wellbeing aids in employee, organizations, and societal positive progress. The present study examines Maori employees, the indigenous people of New Zealand. New Zealand is typically considered a Western and individualistic society, while Maori the indigenous population, who live alongside European New Zealanders, are predominately centered on collectivistic beliefs (House, 2004).

Maori represent the fastest growing ethnicity in New Zealand (Statistics New Zealand, 2007a). Traditionally, Maori have demonstrated a paucity of wellbeing, for example, being over represented in mental health outcomes including anxiety and depression (MaGPIe, 2005; Baxter, Kingi, Tapsell, Durie \& McGee, 2006) as well as being socially disadvantaged, due to high unemployment, and lower income in comparison to European New Zealanders (Statistics New Zealand, 2007b). Durie (2003) noted that it is both laudable and overdue that the New Zealand Government is trying to eliminate the socio-economic disparities between Maori and non-Maori, especially since "Maori aspirations for autonomy were no longer guaranteed after the signing" (p. 3). Combined, these factors make examining Maori workplace wellbeing a crucial issue and the present study highlights positive aspects of Maori beliefs towards whanau applied to the workplace, and tests this towards a wide range of wellbeing components. This study aims to enhance the understanding of indigenous people's wellbeing through understanding indigenous beliefs and values, and applying these to the workplace setting, as potentially one way in which wellbeing disparities with non-Maori may be addressed.

\section{Indigenous Employee Wellbeing}

Csikszentmihalyi (2009) suggested assessment and understanding of the social fabric, norms and values that govern the way we live out our lives is a worthy pursuit for positive psychology. The western world tends to value 
wealth and materialism as markers of success (Kasser \& Ryan, 1996; Kasser, Ryan, Couchman, \& Sheldon, 2004). However, rather than a focus on materialism, Csikszentmihalyi (2009) suggested societies that value community, relationships, and traditional customs offer a greater insight into enhancing individual and societal wellbeing. As such, he called for greater understanding and research by positive psychology into the role that community, relationships and traditions play in wellbeing. Knee and Uysal (In Press) explained the links between autonomy and healthy interpersonal relationships, demonstrating that need fulfilment among couples was associated with deeper understanding, constructive approaches to conflict management and resolution, and health and wellbeing benefits.

Recently, there has been a strong growth in Maori culture, in particular with language undergoing a renaissance, with $24 \%$ of Maori being able to hold an everyday conversation in Te Reo Maori (Maori language) (Statistics New Zealand, 2007). Such a renaissance has lead Maori researchers to reiterate the importance of understanding Te Aro Maori (the Maori world), and recognising and valuing Maori Tikanga (customs) and traditions (Harris, 2007; Walker, 2006). Two significant aspects for Maori are (1) whakapapa and (2) whanau. Whakapapa includes being able to relate to people with whom a common ancestry is shared and relates to maintaining this sense of shared history and community, and includes the notion of valuing shared ancestry and how this community share a common home (marae) as the symbolic place/home for family and ancestors.

Whanau relates to the extended, intergenerational family, and is a crucial concept for Maori because choices and decision-making processes can focus around the implications of these towards whanau. Consequently, these 'family bonds' are given priority over all other considerations in deciding what action to take, with whanau discussions focusing on benefits to the whole whanau rather than just some individuals. For example, Harris (2007) acknowledged that career choices for Maori employees can be made at the whanau level. Critics note that whanau is not a simple 'alternative' term for the nuclear family, as this fails to recognise the vastly different structure for Maori and importance of whanau, which may include intergenerational family structures, possible foster-relationships and other family and community connections and obligations (Edwards, McCreanor \& Moewaka-Barnes 2007; Metge, 1990). Given the embedded nature of traditional cultural values for Maori, the role of traditions, custom and values are likely to be significant for understanding indigenous workers wellbeing (Csikszentmihalyi, 2009). The present study tests the relationship of working with whanau amongst Maori employees, to determine whether this inherently important cultural value triggers aspects of self determination theory, which ultimately improves the wellbeing of Maori employees.

\section{Self Determination Theory}

While Csikszentmihalyi (2009) noted the importance of understanding traditional cultures, Deci and Ryan (2000) have highlighted that at an individual level psychological wellbeing can be enhanced or thwarted through workplace practices. Hence, the present study focuses upon the way the cultural traditions of Maori employees applied to the workplace may enhance their wellbeing, and we use components of self determination theory (SDT) to understand the way these values may influence wellbeing. SDT is a meta-theory that suggests individuals are (1) growth-oriented, and (2) interaction with their environment can either support or thwart wellbeing (Deci \& Ryan, 2000). SDT maintains that individuals have an innate striving to actualise their potential, by increasing their knowledge, cultivating their interests, seeking challenges and being able to integrate these experiences into an authentic sense of self. As such, humans aim for harmonious integration into the larger social environment and successful integration of self and environment enhances wellbeing (Vansteenkiste, Neyrinck, Niemiec, Soenens, De Witte, \& Van den Broeck, 2007).

Within SDT, it is also acknowledged that individuals can become passive and counter-productive (Deci \& Ryan, 2000). The assumption that humans are inherently active organisms does not imply that this tendency happens automatically, and SDT maintains that the growth oriented nature of individuals requires fundamental "nutrients" and conditions to facilitate wellbeing (Deci \& Ryan, 2000). The social context can therefore cultivate or refute an individuals' growth. As such, SDT takes into account both individuals' optimal functioning and wellbeing, and malfunctioning, and studies the conditions which stimulate the former or elicit the latter (Ryan \& Deci, 2001). From a practical point of view these assumptions suggest that individuals can best be motivated by the active supporting of their potential (Vansteekiste at al., 2007). According to SDT, employees are likely to display optimal performance and wellbeing in a context in which their growth and natural tendencies are supported and encouraged. Applied to indigenous employees, greater wellbeing should be exhibited when their traditional cultural values and beliefs are supported. Chirkov (In Press) noted the importance of culture for indigenous people, especially towards having their needs met, such as autonomy. This is because through autonomy, a person may become fully developed and thus able to reflect on their cultural influences (Chirkov, In Press). Consequently, the exploration of cultural dimensions using a SDT framework is both applicable and highly warranted especially as the colonization of Maori by the British and the subsequent treaty signing removed Maori aspirations for autonomy (Durie, 2006).

\section{Basic Psychological Needs}

SDT suggests that wellbeing is enhanced by the satisfaction of basic psychological needs for autonomy, competence and relatedness. Conditions that satisfy one's psychological needs facilitate wellbeing, whereas conditions that impede need satisfaction thwart wellbeing and growth (Deci \& Ryan, 2000). The satisfaction of these psychological needs is related to increased wellbeing (Sheldon, Ryan, \& Reis, 1996; Sheldon \& 
Elliot, 1999), vitality, (Reis, Sheldon, Gable, Roscoe, \& Ryan, 2000), positive affect (Sheldon, Elliot, Kim, \& Kasser, 2001), this has been found across different cultures (e.g. Deci, Ryan, Gange, Leone, Usunov, Komasheva, 2001) and by time and gender (Chirkov, Ryan, Kim \& Kaplan, 2003). As these results have been found across professional levels, sectors and cultures (e.g., Deci \& Ryan, 2000), SDT claims that satisfaction of these needs yield universal positive associations and these are explained in more detail below.

Autonomy: Autonomy is defined as people's desire to experience ownership of their behaviour and to act with a sense of volition. Autonomy literally means 'selfgoverning'. (Ryan, Huta \& Deci 2008). Autonomy can be achieved through having the ability to make personal choices, and feeling like an initiator of one's own actions (Sheldon \& Filak, 2008; Deci \& Ryan, 2000; Sheldon \& Niemiec, 2006). Knee and Uysal (In Press) asserted that autonomy is important for healthy personal relationships, suggesting these effects may be extended to non-Western countries. Furthermore, the need for autonomy aligns well with the Maori concept of tino rangatiratanga, which relates to self-determination and sovereignty (Walker, 2004). Competence: Refers to succeeding at optimally challenging tasks and attaining desired outcomes (White 1959).. For example, engaging in or undertaking activities in the workplace that enhance a feeling of growth and development is likely to enhance feelings of competence and aid in mastering of that workplace environment. Given that Maori have unemployment rates in excess of the European population (12.6\% compared to $4.0 \%$, New Zealand Statistics, 2007b), simply undertaking work may provide a strong sense of competence for Maori (e.g. unemployment research- Vansteenkiste, Lens, De Witte, \& Feather, 2005).. Similarly, Durie (2003) asserted that meaningful work for Maori employees is likely to provide greater dignity and self determination, and we suggest working with whanau should be seen as more meaningful. Relatedness: The need for relatedness is defined as the striving for close and intimate relationships and the desire to achieve a sense of connection and belongingness and a sense of mutual respect, caring, and reliance on others (Ryan \& Deci, 2001; Baumeister \& Leary, 1995), and this is found in the workplace (Simon, Judge \& HalvorsenGanepola, 2010). For Maori, working with whanau would satisfy both cultural needs and needs towards relatedness. By interacting and working with whanau, Maori employees would be able to meet their needs of belonging and connectedness as well as fundamental cultural values of being with extended family.

\section{Additional Family Benefits}

Although SDT finds autonomy, competence and relatedness matter in the workplace and to wellbeing in general (Deci \& Ryan, 2000); recent research has suggested that one's wellbeing and relatedness are higher on the weekend, termed the weekend effect. This is because at the weekend individuals are able to interact with family and as such have greater access to relatedness needs being met (Ryan, Bernstein, \& Brown, 2010). Ryan et al. (2010) found wellbeing was significantly higher from Friday evenings through Sunday afternoon, and was reflected in better moods, higher sense of vitality, and fewer physical symptoms. Overall, greater ability to connect with family on weekends enhanced wellbeing and satisfaction of psychological needs. This is applicable to the present study because the benefits of weekends for employees (being and interacting with family), could be transposed into the workplace by close working relationships with whanau for Maori employees.

\section{Whanau Connections \& Hypotheses}

The present study suggests Maori employees engaging in working relationships with whanau will enhance wellbeing through satisfying factors associated with autonomy, competency and relatedness. Furthermore, the benefits of working with family are likely to be akin to the weekend effect (Ryan et al., 2010) which should provide additional benefits to these employees. Not only has there been little research on indigenous employees as a sole-sample group, but few studies have explored specific cultural aspects amongst employees. Csikszentmihalyi (2009) argued that exploring indigenous people's wellbeing should include cultural (values, beliefs and customs) and social (such as the workplace) dimensions of wellbeing. Consequently, a comprehensive framework for understanding indigenous employee wellbeing includes the social and cultural drivers of wellbeing, such as indigenous societies community and relatedness aspirations (Csikszentmihalyi, 2009) and an understanding of how to enhance individual's psychological needs of within a workplace context (Deci \& Ryan, 2008).

The present study uses whanau connections as a measure for exploring Maori employee's relationships with their whanau in the workplace. Beyond simply working with whanau, we suggest the connections between whanau towards sharing work, interactions, and stories, regarding both work and home issues, are likely to build confidence and satisfaction amongst Maori employees such that their wellbeing is enhanced. The context of indigenous employees and their interactions with whanau in the workplace has not previously been explored. In a western economic context, hiring and working with one's family is referred to as nepotism and has negative connotations (Arasli \& Tumer, 2008), with the potential for adverse outcomes including firm performance (Perez-Gonzalez, 2006; Lin \& Hu, 2007). However, in a collectivist setting, employing and working with family and whanau is not considered in a negative light by Maori as it might be with western economies. Indeed, such employment relationships might be more common today with the increase in Maori participation in the workforce and the rise of Maori business. The present paper suggests this is an area of the employment relationship that needs greater exploration to understand whether Maori employees working with and interacting with whanau enjoy greater wellbeing than Maori employees not enjoying closer working relationships with whanau.

Towards measuring whanau connections, we engage the work-family literature because importantly, while work can be detrimental through conflict (Greenhaus \& 
Beutall, 1985), it has also been found to be positive and enriching (Greenhaus \& Powell, 2006). Importantly, studies have established a strong link between issues and actions occurring in the workplace and the home that are both related and distinct (e.g. Haar \& Bardoel, 2008). This is especially relevant for Maori employees and our conceptualization of whanau connections. Engaging, interacting and mixing with family in the workplace is likely to produce issues around both the workplace and family/home and indeed, given the fundamental role of whanau, this may be even more strongly enacted and important when working together. Consequently, we conceptualize whanau work connections as relating to the engagement amongst related indigenous employees in the workplace, dealing specifically with workplace issues and interactions. Conversely, we conceptualize whanau home connections as relating to the engagement amongst related indigenous employees dealing specifically with home issues and interactions but occurring in the workplace. Given that work-family studies have found different effects from work and family based dimensions (Eby, Casper, Lockwood, Bordeaux, \& Brinleya, 2005), we might expect our whanau connections dimensions to have distinct influences towards outcomes, although we do not hypothesize one dimension over the other due to the exploratory nature of this research. However, we acknowledge that such a distinction is likely given studies finding different influences from the work and family sources towards outcomes.

Using SDT as an overarching lens, we suggest higher whanau connections will benefit Maori employees and lead to lower mental health issues and higher satisfaction outcomes. The SDT literature relating to the needs satisfaction, has found strong support for having needs towards autonomy, relatedness and competence met linking to higher wellbeing. Baumesiter and Leary (1995) suggested that higher frequency towards seeing and being with others characterises the depth of relationships and ultimately enhances strong feelings of attachment, intimacy, and commitment by people with others. This effect should be particularly strong among Maori employees, due to their strong whanau relationships and the ability to have cultural, psychological and interpersonal needs met by working and interacting with family. Furthermore, Baumesiter and Leary (1995) noted that the need to belong is far greater than simple affiliation and attachment, and is enhanced by time and contact, suggesting long-term and intimate social contact would provide for satisfying the need to belong, which would not be available in interactions with strangers and acquaintances. While the workplace isn't necessarily the best place for such satisfying social contacts, we suggest Maori working with whanau are likely to have these met.

Within the organizational context, need satisfaction has been shown to relate positively to employees' work outcomes including job satisfaction, commitment, job performance, motivation, and negatively towards employee mental health including burnout, anxiety and depression (Greguras \& Diefendorff, 2009; Vansteenkiste, Neyrinck, Niemiec, Soenens, De Witte, \& Van den Broeck, 2007; Deci \& Ryan, 2000). Consequently, we suggest that Maori employees working with whanau are more likely to report lower mental health outcomes and higher satisfaction outcomes.

Hypothesis 1: Higher (a) whanau work connections and (b) whanau home connections will be related to higher job satisfaction.

Hypothesis 2: Higher (a) whanau work connections and (b) whanau home connections will be related to l higher cultural satisfaction.

Hypothesis 3: Higher (a) whanau work connections and (b) whanau home connections will be related to lower anxiety

Hypothesis 4: Higher (a) whanau work connections and (b) whanau home connections will be related to lower depression.

\section{Interaction Effects}

In addition to direct effects, we also test the potential interaction between work and home dimensions of whanau connections. It has been noted that studies exploring aspects of work and family should explore both sides, because resources may be transferred from one domain into the other domain, creating enhancing effects (Graves et al., 2007; Aryee, Srinvias, \& Tan, 2005). Ford, Heinen and Langkamer (2007) stated that "organizations cannot optimize employee satisfaction without considering nonwork influences" (p. 74). As such, we argue that whanau connections are likely to lead to more positive outcomes through reducing mental health issues and enhancing satisfaction outcomes. Furthermore, while the influences from whanau connections may differ from whether it occurs in the work and home domain, we suggest they may interact with each other providing greater benefit towards reducing mental health and enhancing satisfaction. This also responds to calls for research that examines how processes linking family and work domains influence work and family outcomes (Graves et al., 2007). Furthermore, there is empirical evidence that supports cross-domain effects towards outcomes (Haar \& Roche, 2010), and as such, we suggest that given whanau connections from either work and home are likely to meet the psychological needs of Maori employees, we test for them augmenting each other, and thus creating additional benefits for these employees.

Hypothesis 5: Whanau work connections and whanau home connections will interact with each other, leading to higher satisfaction (job and cultural) at high levels of both connections.

Hypothesis 6: Whanau work connections and whanau home connections will interact with each other, leading to lower mental health (anxiety and depression) at high levels of both connections.

\section{Method}

Sample and Procedure 
Because Maori make up only $12 \%$ of the New Zealand workplace, purposeful sampling was undertaken. As such, two geographical locations of New Zealand with strong Maori populations were chosen and data were collected from 12 New Zealand organizations within these regions. Surveys were hand delivered by one of the researchers and collected from a secure drop box. CEOs or Senior Managers were met personally and had the research explained to them. These individuals agreed to participate and sent all employees a notice or email about the research encouraging Maori employees to participate. Data collection was undertaken in two waves with a two month gap between surveys to eliminate issues of common method variance, with surveys matched by a unique employee code. Survey One contained the measures for whanau connections and demographic variables. Survey Two had the outcome measures. From a total pool of 340 Maori employees, 241 participants responded (69.9\% response rate) to the first survey. The follow up survey produced a total of 197 responses, resulting in an overall response rate of $57.1 \%$ for surveys one and two. On average, the participants were 38.7 years old $(\mathrm{SD}=11.8$ years), married $(73 \%)$, parents $(75 \%)$, and female (51\%). Respondents worked 38.4 hours per week $(\mathrm{SD}=7.1$ hours) and had job tenure of 4.1 years $(\mathrm{SD}=4.0$ years). Education was well spread with $20 \%$ holding a high school qualifications, $37.3 \%$ a technical college qualification, $33.3 \%$ a university degree, and $9.4 \%$ a postgraduate qualification.

\section{Measures}

\section{Predictor Variables}

Whanau connections were measured with 7-items created for the present study, coded 1=strongly disagree, $5=$ strongly agree. To test the factor structure of the seven items, an exploratory factor analysis (principal components, varimax rotation) was run to explore the nature of the measure. Items used, factor analyses outcomes, and reliabilities are shown in Table 1.

\section{Insert Table 1 about here}

Overall, two factors emerged: Whanau Work Connections $(\alpha=.87)$ and Whanau Home Connections $(\alpha=.75)$.

\section{Analysis}

Hierarchical regression analysis was used to analyze the data with job satisfaction, cultural satisfaction, anxiety, and depression as the criterion variables. Control variables were entered in Step 1 (age, gender, education, indigenous language, and tribal affiliations) and Step 2 had the two whanau connection dimensions. To test for moderation, the interaction between whanau work connections and whanau home connections were entered in Step 3. To address issues of multi-collinearity, mean centering of the interaction terms was undertaken (Aiken \& West, 1991).

\section{Results}

Results of the hierarchical regression for Hypotheses 1 to 6 are shown in Table 2.

Insert Table 2 about here

Table 2 shows that whanau work connections is significantly associated with job satisfaction $(\beta=.37, \mathrm{p}<$ $.001)$ and cultural satisfaction $(\beta=.50 \mathrm{p}<.001)$, while whanau home connections are significantly associated with anxiety $(\beta=-.25, \mathrm{p}<.01)$ and depression $(\beta=-.26$, $\mathrm{p}<.05)$. From the $\mathrm{R}^{2}$ Change figures in Step 2 we can see that whanau connections account for modest amounts of mental health with $4 \%(\mathrm{p}<.05)$ towards anxiety and $5 \%$ $(\mathrm{p}<.05)$ towards depression, but accounts for larger amounts of variance towards job satisfaction $(11 \%, \mathrm{p}<$ $.001)$ and cultural satisfaction $(27 \%, \mathrm{p}<.001)$. Overall, there is support for Hypotheses $1 \mathrm{a}, 2 \mathrm{a}, 3 \mathrm{~b}$, and $4 \mathrm{~b}$.

Table 3 also shows that there is a significant interaction between whanau work connections and whanau home connections towards all outcomes. To facilitate interpretations of the significant moderator effects, the interactions are presented in Figures 1 to 4.

\section{Insert Figure 1-4 about here}

Plots of the interaction terms for satisfaction (Figures 1 and 2) are similar, showing that when whanau work connections is low, there is little difference between respondents with low and high levels of whanau home connections, with respondents with low whanau home connections reporting slightly higher satisfaction. When whanau work connections are high, respondents with low whanau home connections report a slight increase in satisfaction while those with high whanau home connections report a significant increase in satisfaction. Overall, there is support for the cumulative effects of whanau connections from both the work and home domains leading to higher satisfaction.

Plots of the interaction terms for mental health (Figures 3 and 4) are similar, showing that when whanau work connections is low, there is a significant difference between respondents with low and high levels of whanau home connections, with respondents with high whanau home connections reporting lower mental health issues. When whanau work connections are high, respondents with low whanau home connections report a significant increase in mental health issues while those with high whanau home connections report a slight decrease in 
mental health issues. Overall, there is support for the cumulative effects of whanau connections from both the work and home domains leading to lower mental health issues.

\section{Discussion}

Baumesiter and Leary (1995) suggested that only social contact that is long-term and intimate, can provide for satisfying the need to belong and relatedness under SDT. As such the need to belong is not available in interactions with strangers and acquaintances usually found in the workplace. Thus, the workplace is not normally associated with the opportunity for longer term and more nurturing relationships to develop. Consequently, for belonging at work to be enhanced, a greater emotional commitment to a person in the workplace is required beyond mere attachment as a workmate. The present study drew on various aspects of SDT and findings relating to being with family such as the weekend effect (Ryan et al., 2010) and tested a measure of whanau connections on a sample of Maori employees. Maori are the indigenous people of New Zealand, and research on Maori has predominantly been negative and discouraging (Smith, 1999). Given that whanau, the extended family unit, is a fundamental and essential part of Maori culture, we suggested that workplace connections with whanau would meet the needs satisfaction of Maori employees and be beneficial and enhancing. Consequently, this research addresses a number of calls for research (Csikszentmihalyi, 2009; Smith, 1999) and provides new and unique contexts for extending SDT theory into indigenous employees and their cultural values.

Factor analysis confirmed our measure and showed two highly related but distinct measures of whanau connections, towards work and home interactions. Correlation analysis showed they were similarly related to most outcomes, although not universally, showing the dimensions were likely to have different influences on different outcomes. This was confirmed by regression analysis, which showed different effects from each dimensions. For example, while whanau home connections were a significant predictor of mental health outcomes, whanau work connections was only a significant predictor of satisfaction outcomes. Overall, the findings suggest that for Maori working with whanau and interacting and discussing work and home aspects, wellbeing was enhanced due to the ability to sustain these long-term and intimate relationships with family in the workplace. This was particularly true towards whanau connections about the home towards stress and anxiety. While the majority of the literature suggests work interactions are more likely to influence stress and mental health (Eby et al., 2005), the importance of the family unit on Maori might provide insight into why the whanau home connections was more important towards reducing mental health issues. Furthermore, enriching aspects from the home have been found to reduce mental health issues rather than those from the work (Haar \& Bardoel, 2008), highlighting that while the workplace can provide the strongest increase in mental health issues, reductions are likely to come from the home and our findings support this notion. Furthermore, this may also reinforce the importance of the home unit for Maori employees.

Csikszentmihalyi (2009) referred to undeveloped societies who had richer lives by having different forms of recognition and rewards that were not reduced to a monetary metric, such as community, relationships, customs and traditions, and called for greater understanding by positive psychology to recognize and explore this behavior. The present study suggests this might be applicable for Maori employees towards their indigenous cultural traditions especially in the workplace setting. Overall, the present study finds that by examining a cultural norm and practice of valuing and interacting with whanau, the wellbeing of Maori employees was enhanced. Furthermore, using Self Determination Theory (SDT) and satisfaction of an individual's psychological needs (Ryan et al., 2008), allowed for greater understanding of how indigenous workers wellbeing can be potentially enhanced through cultural factors meeting psychological needs, and overall this was supported. The present study explored the benefits for Maori in working with whanau (family and extended family), as family is a central principle of Maori culture, and supports the argument that cultural beliefs (whanau) and workplace practices (working with whanau), can together, create a mechanism for enhancing indigenous employee wellbeing (Csikszentmihalyi, 2009).

\section{Conclusions}

The current study examined social and cultural aspects of wellbeing in relation to psychological and workplace outcomes. This was in response to calls that a comprehensive framework for understanding indigenous employee wellbeing should include social and cultural drivers of wellbeing, such as indigenous community and relatedness aspirations (Csikszentmihalyi, 2009). Overall, the present study supports this in our study of New Zealand Maori, and shows how understanding cultural aspects in the workplace can aid our understanding of how to enhance indigenous individual's psychological needs and wellbeing (Ryan \& Deci, 2008). The present study supports SDT as a theoretical lens for understanding indigenous employee wellbeing, and highlights how this theory can be used to understand indigenous cultural factors and how these can enhance indigenous wellbeing. The present study provides an initial direction for researchers on indigenous employees and should provide encouragement for researchers seeking to applying cultural values and beliefs towards understanding the wellbeing of indigenous peoples.

\section{References}

Acs, Z. and Audretsch, D. (1990). The determinants of small-firm growth in US manufacturing. Applied Economics, 22, 143-153.

Addison, J. and Wagner, J. (1994). U.S. unionism and R\&D investment: Evidence from a simple cross- 
country test. Journal of Labor Research, 15, 191197.

Aiken, L. G. \& West, S. G. (1991). Multiple Regression: Testing and Interpreting Interactions. Newbury Park CA: Sage.

Allen, S. (1988). Productivity levels and productivity change under unionism. Industrial Relations, 27, 94-113.

Arasli, H. \& Tumer, M. (2008). Nepotism, favoritism and cronyism: A study of their effects on job stress and job satisfaction in the banking industry of north Cyprus. Social Behavior and Personality: An International Journal, 36(9), 1237-1250.

Aryee, S., Srinvias, E. S., \& Tan, H. H. (2005). Rhythms of life: Antecedents and outcomes of work-family balance in employed parents. Journal of Applied Psychology, 90(1), 132-146.

Axtell, C., Wall, T., Stride, C., Pepper, K., Clegg, C., Gardne, P., \& Bolden, R. (2002). Familiarity breeds content: The impact of exposure to change on employee openness and well-being. Journal of Occupational and Organizational Psychology, 75, 217-231

Bamber, G. (1988). Technological change and unions. In Hyman, R. and Streeck, W. (1988) New Technology and Industrial Relations. Oxford: Basil Blackwell.

Baumeister, R.F. \& Leary, M. (1995). The need to belong: Desire for interpersonal attachments as a fundamental human motivation. Psychological Bulletin, 117(3), 497-529.

Baxter, J., Kingi, T. K., Tapsell, R., Durie, M. \& McGee, M. A. (2006). Prevalence of mental disorders among Maori in Te Rau Hinengaro: The New Zealand Mental Health Survey. Australian and New Zealand Journal of Psychiatry, 40(10), 914-923.

Block, R. (1995). Labor law, economics, and industrial democracy: A reconciliation. Industrial Relations, 34, 402-416.

Bok, D. and Dunlop, J. (1970). Labor and the American Community. New York: Simon and Schuster.

Bronars, S. and Deere, D. (1993). Unionization, incomplete contracting, and capital investment. Journal of Business, 66, 117-132.

Bronars, S., Deere, D. and Tracy, J. (1994). The effects of unions on firm behavior: An empirical analysis using firm level data. Industrial Relations, 33, 426-451.

Chirkov, V. (In Press). Dialectical Relationships among Human Autonomy, the Brain, and Culture. In Chirkov, V., Ryan, R., \& Sheldon, K. (Eds). Human Autonomy in Cultural Contexts:
Perspectives on the Psychology of Agency, Freedom, and People's Well-Being. Springer.

Chirkov, V., Ryan, R. M., Kim, Y., \& Kaplan, U. (2003). Differentiating autonomy from individualism and independence: A selfdetermination theory perspective on internalization of cultural orientations and well-being. Journal of Personality and Social Psychology, 84(1), 97-110

Csikszentmihalyi, M. (2009). The promise of positive psychology Psychological Topics, 18 (2), 203-211.

Deci, E. L., \& Ryan, R. M. (2000). The "what" and the "why" of goal pursuits: Human needs and the selfdetermination of behaviour. Psychological Inquiry, 11, 227-268.

Deci, E. L., \& Ryan, R. M. (2008). Facilitating optimal motivation and psychological well-being across life's domains. Canadian Psychology, 49, 1423.

Deci, E. L., Ryan, R. M., Gange, M., Leone, D. R., Usunov, J., \& Komasheva, B. P. (2001). Need satisfaction, motivation, and well-being in the work organizations of a former eastern bloc country: a cross-cultural study of SelfDetermination. Personality and Social Psychology Bulletin, 2(8), 930-942.

Diener, E. \& Sligman, M.E.P. (2002). Very happy people Psychological Sciences 13(1), 181-184.

Diener, E., Emmons, R.A., Larsen, R.J., \& Griffin, S. (1985). The Satisfaction with Life Scale. Journal of Personality Assessment, 49(1), 71-74.

Durie, M. (2003). Nga Kahui Pou: Launching Maori Futures. Wellington, New Zealand: Huia Publishers.

Durie, M. (2006). Te Mana, Te Kawanatanga: The Politics of Maori Self-Determination. Wellington, New Zealand: Oxford University Press.

Eby, L., Casper, W., Lockwood, A., Bordeaux, C., \& Brinleya, A. (2005). Work and family research in IO/OB: Content analysis and review of the literature (1980-2002). Journal of Vocational Behavior, 66(1), 124-197.

Edwards, S., McCreanor, T., Moewaka-Barnes, H., \& Whariki, T. R. (2007). Maori family culture: A context of youth development in Counties/Manukau. New Zealand Journal of Social Sciences Online, 2, 1-15.

Ford, M. T., Heinen, B. A., and Langkamer, K. L. (2007). Work and Family Satisfaction and Conflict: A Meta-analysis of Cross-domain Relations. Journal of Applied Psychology, 92(1), 57-80. 
Graves, L. M., Ohlott, P. J., and Ruderman, M. N. (2007). Commitment to Family Roles: Effects on Managers' Attitudes and Performance. Journal of Applied Psychology, 92(1), 44-56.

Greenhaus, J.H., \& Beutell, N. J. (1985). Sources of conflict between work and family roles. Academy of Management Review, 10(1), 76-88.

Greenhaus, J. H. \& Powell, G. N. (2006). When work and family are allies: A theory of work-family enrichment. Academy of Management Review, 31(1), 72-92.

Greenhaus, J., Parasuraman, S., \& Wormley, W. (1990). Effects of race on organizational experiences, job performance evaluations and career outcomes. Academy of Management Journal, 33(1), 64-86.

Greguras, G. J. \& Diefendorff, J. M. (2009). Different fits satisfy different needs: Linking personenvironment fit to employee commitment and performance using self-determination theory. Journal of Applied Psychology, 94(2), 465-477.

Haar, J. M. \& Bardoel, A. (2008). Work-family positive spillover predicting outcomes: A study of Australia employees. Asia Pacific Journal of Human Resources, 46(3), 275-289.

Haar, J. \& Roche, M. (2010). Family supportive organisation perceptions and employee outcomes: The mediating effects of life satisfaction. International Journal of Human Resource Management, 21(7), 999-1014.

Harris. N.T.A. (2007). Work life balance: A Maori Women's perspective. Auckland: Auckland University of Technology.

House, R.J. (2004). Culture, leadership and organizations: The GLOBE study of 62 societies. Sage, USA.

Kasser, T. \& Ryan, R.M. (1996). Further examining the American dream: Differential correlates of intrinsic and extrinsic goals. Personality and Social Psychology Bulletin, 22, 280-287.

Kasser, M., Ryan, R.M., Couchman, C.E., \& Sheldon, K.M. (2004). Materialistic values: Their cases and consequences. In T. Kasser \& A.D. Kanfer (Eds). Psychology and consumer cultures: The struggle for a good life in a materialistic world (pp. 11-28). Washington, DC: American Psychological Association

Knee,C.R. \& Uysal, A. (In Press). The role of autonomy in promoting healthy dyadic familial and parenting relationships across cultures. In Chirkov, V., Ryan, R., \& Sheldon, K. (Eds). Human Autonomy in Cultural Contexts: Perspectives on the Psychology of Agency, Freedom, and People's Well-Being. Springer

Kossek, E. E. \& Ozeki, C. (1998). Work-family conflict, policies and the job-life satisfaction relationship: A review and directions for organizational behaviorhuman resources research. Journal of Applied Psychology, 83(2), 139-149.

Lin, S. \& Hu, S. (2007). A family member or professional management? The choice of a CEO and its impact on performance. Corporate Governance, 15, 1348-1362.

MaGPIe. (2005). Mental disorders among Maori attending their general practitioner. Australian and New Zealand Journal of Psychiatry, 39(5), 401-406

Metge, J. (1990). Te Rito o te Harakeke: Conceptions of the Whanau. Journal of the Polynesian Society, 99(1), 55-92.

Motowidlo, S. J., Packard, J. S., \& Manning, M. R. Metge, J. (1986). Occupational stress: Its causes and consequences for job performance. Journal of Applied Psychology, 71(4), 618-629.

Morrow, P. (1983). Concept redundancy in organizational research: The case of work commitment. Academy of Management Review, 8(3), 486-500.

Pavot, W. \& Diener, E. (2008). The satisfaction with life scale and the emerging construct of life satisfaction. The Journal of Positive Psychology, 3(2), 137-152.

Perez-Gonazalez, F. (2006). Inherited control and firm performance. American Economic Review, 96, $1559-1588$

Reis, H. T., Sheldon, K. M., Gable, S. L., Roscoe, J., \& Ryan, R. M. (2000). Daily well being: The role of autonomy, competence, and relatedness. Personality and Social Psychology Bulletin, 26, 419-435.

Ryan, T.P. (1997). Modern Regression Methods, New York: Wiley.

Ryan, R. M., Bernstein, I., \& Brown, K. W. (2010). Weekends, work and, well-being. Psychological need satisfaction and day of the week effects on mood, vitality, and physical symptoms. Journal of Social and Clinical Psychology, 29(1), pp. 95-122.

Ryan, R. M., \& Deci, E . L. (2001). On happiness and human potentials: A review of research on hedonic and eudaimonic well-being. Annual Review of Psychology. 52(1), 141- 166.

Ryan, R. M., Huta, V. Deci, E. L. (2008). Living well: a Self Determination theory perspective on 
eduaimonia. Journal of Happiness Studies, 9, 139-170.

Sheldon, K.M., Elliot, A.J. (1999). Goal striving, need satisfaction and longitudinal well-being. The self-concordance model. Journal of Personality and Social Psychology, 76(3), 482-497.

Sheldon, K. M., Elliot, A. J., Kim, Y., \& Kasser, T. (2001). What Is Satisfying About Satisfying Events? Testing 10 Candidate Psychological Needs. Journal of Personality and Social Psychology, 80(2), 325-339.

Sheldon, K., \& Filak, V. (2008). Manipulating autonomy, competence, and relatedness support in a game-learning context: new evidence that all three needs matter. British Journal of Social Psychology, 47, 267-283.

Sheldon, K., \& Niemiec, C. (2006). It's not just the amount that counts. Balance need satisfaction also affects wellbeing. Journal of Personality and Social Psychology, 91(2), 231-341.

Sheldon, K. M., Ryan, R., Reiss, H.T. (1996). What makes for a good day? Competence and autonomy in the day of a person. Personality and Social Psychology Bulletin. 22(12), 1280-1288.

Sheldon, K. M., Elliot, A. J., Ryan, R. M., Chirkov, V., Kim, Y., Wu, C., Demir, M., \& Sun, Z. (2004). Self-concordance and subjective well-being in four cultures. Journal of Cross-Cultural Psychology, 35(2), 209-223.

Simon, L. S., Judge, T. A., \& Halvorsen-Ganepola, D. K. (2010). In good company? A multi-study, multi-level investigation of the effects of co-worker relationships on employee well-being. Journal of Vocational Behaviour, 76(3), 534-546.

Smith, L.T. (1999). Decolonizing Methodologies: Research and Indigenous People, London: Zed Books Ltd

Statistics New Zealand. (2007a). QuickStats about Culture and Identity: 2006 Census. Wellington: Statistics New Zealand.

Statistics New Zealand. (2007b). QuickStats about Incomes: Census 2006. Revised 27 March 2007, Wellington: Statistics New Zealand.

Te Puni Korkiri (2009). Moni Utunga Māori: Māori Earnings. Wellington: Te Puni Korkiri.

Vansteenkiste, M., Lens, W., De Witte, H., \& Feather, I. (2005). Understanding unemployed people's job search behaviour, unemployment experience and wellbeing: A comparison of expectancy-value theory and self-determination theory. British Journal of Social Psychology, 44(2), 269-287.
Vansteenkiste, M., Neyrinck, B., Niemiec, C.P., Soenens, B., De Witte, H., \& Van den Broeck, A. (2007). On the relations among work value orientations, psychological need satisfaction, and job outcomes: A self-determination theory approach. Journal of Occupational and Organizational Psychology, 80(25), 251-277.

Walker, R. (2004). Ka Whawhai Tonu Matou: Struggle without End (Revised Edition). Auckland: Penguin Books

Walker, T. (2006). Whanau is Whanau: Blue Skies Report. Wellington: Families Commission.

White, R. W. (1959). Motivation reconsidered. The concept of competence. Psychological Review, 66(5), 297-333.

Wright, T. A. \& Quick, J. C. (2009). The emerging positive agenda in organizations: Greater than a trickle, but not yet a deluge. Journal of Organizational Behaviour, 30, 147-159. 
Table 1. Exploratory Factor Analysis for Whanau Connections

\begin{tabular}{|c|c|c|}
\hline \multirow{2}{*}{$\begin{array}{l}\text { The following questions relate to how you interact with both your family and whanau (extended family) while at work } \\
\text { (coded (1)=strongly disagree, (5)=strongly agree). }\end{array}$} & \multicolumn{2}{|c|}{ Factor Loadings } \\
\hline & $\begin{array}{c}\text { Whanau Work } \\
\text { Connections }\end{array}$ & $\begin{array}{l}\text { Whanau Home } \\
\text { Connections }\end{array}$ \\
\hline 1. I am able to catch up with my whanau at work & .921 & .204 \\
\hline 2. Having my whanau as co-workers makes communication about work issues easier & .919 & .258 \\
\hline 3. I make regular time to my whanau during my week because this connection is important to me & .688 & .347 \\
\hline 4. Having my whanau as co-workers makes communication about home issues easier & .192 & .787 \\
\hline 5. I sometimes spend my working week working with my whanau & .191 & .785 \\
\hline 6. My whanau like discussing home issues at workplace & .303 & .730 \\
\hline 7. My whanau like discussing workplace issues at home & .231 & .616 \\
\hline Eigenvalues & 2.386 & 2.376 \\
\hline Percentage variance & 34.080 & 33.940 \\
\hline Number of items in measures & 3-items & 4-items \\
\hline Cronbach's Alpha & .87 & .75 \\
\hline
\end{tabular}


Table 2. Hierarchical Moderated Regression Analysis for Outcomes

\begin{tabular}{|c|c|c|c|c|}
\hline \multirow[b]{2}{*}{ Variables } & \multicolumn{4}{|c|}{ OUTCOMES } \\
\hline & Job Satisfaction & Cultural Satisfaction & Anxiety & Depression \\
\hline \multicolumn{5}{|l|}{ Step 1 (Controls) } \\
\hline Age & -.06 & -.05 & -.11 & -.15 \\
\hline Gender & .13 & $.18^{*}$ & .02 & .07 \\
\hline Education & .02 & .14 & $.21 * *$ & $.24 * *$ \\
\hline Te Reo Maori & .09 & .08 & -.05 & -.02 \\
\hline Tribal Affiliations & -.15 & -.06 & -.12 & -.10 \\
\hline $\mathrm{R}^{2}$ change & .04 & .06 & .06 & $.08^{*}$ \\
\hline \multicolumn{5}{|l|}{ Step 2 (Predictors) } \\
\hline Whanau Work Connections & $.37 * * *$ & $.50 * * *$ & .09 & .03 \\
\hline Whanau Home Connections & -.03 & -.11 & $-.25 * *$ & $-.26^{*}$ \\
\hline $\mathrm{R}^{2}$ change & $.11 * * *$ & $.17 * * *$ & $.04 *$ & $.05^{*}$ \\
\hline \multicolumn{5}{|l|}{ Step 3 (Interactions) } \\
\hline $\begin{array}{l}\text { Whanau Work Connections x } \\
\text { Whanau Home Connections }\end{array}$ & $.19 * *$ & $.21 * *$ & $-.16^{*}$ & $-.11 \dagger$ \\
\hline $\mathrm{R}^{2}$ change & $.03 *$ & $.04 * *$ & $.02 *$ & .01 \\
\hline Total $\mathrm{R}^{2}$ & .18 & .27 & .12 & .14 \\
\hline Adjusted $\mathrm{R}^{2}$ & .14 & .23 & .08 & .09 \\
\hline F Statistic & $4.592 * * *$ & $6.613 * * *$ & $2.784 * *$ & $2.941 * *$ \\
\hline
\end{tabular}

$\dagger \mathrm{p}<.1, * \mathrm{p}<.05, * * \mathrm{p}<.01, * * * \mathrm{p}<.001$, Standardized regression coefficients. All significance tests were single-tailed. 
Figure 1. Prediction Model for Whanau Connections towards Job Satisfaction

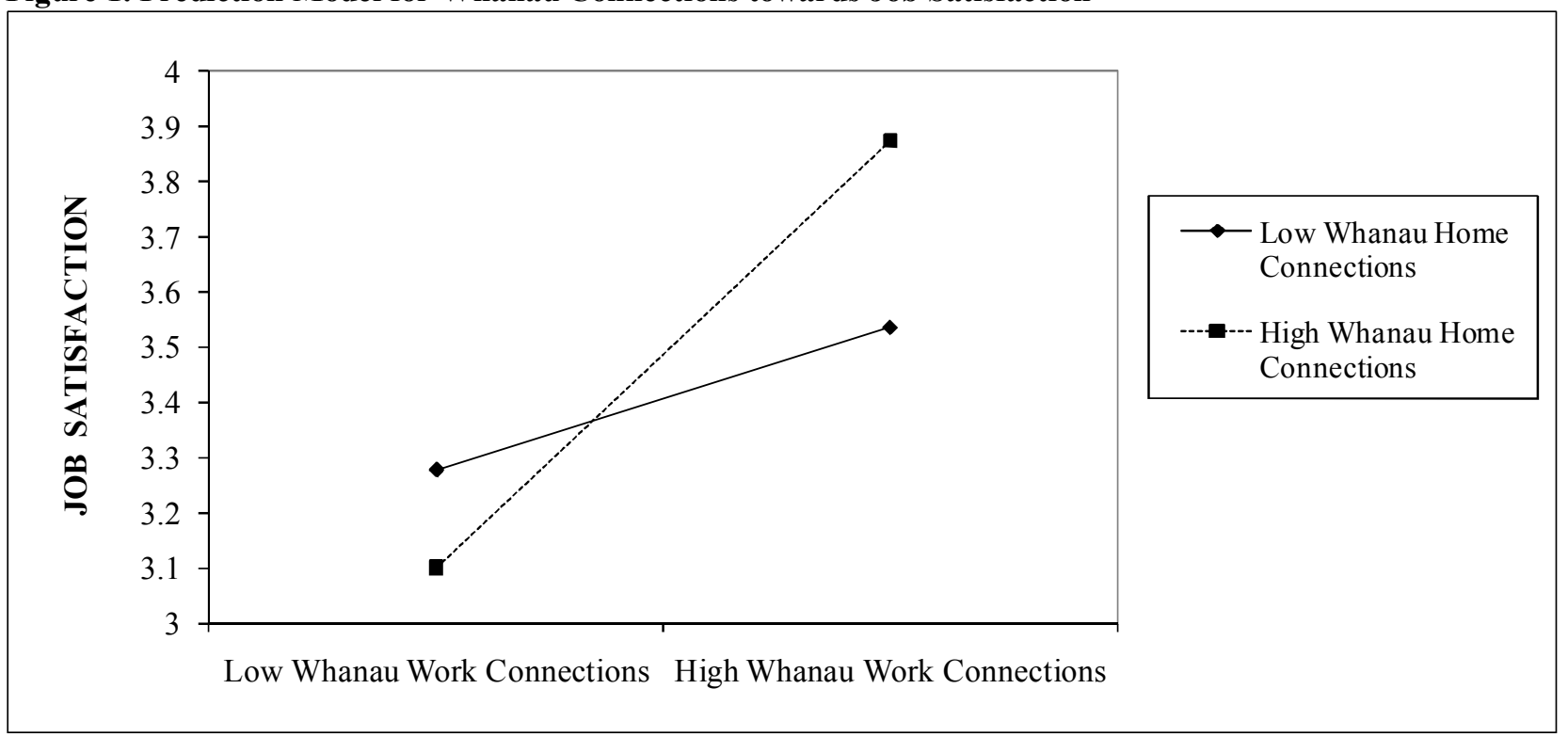

Figure 2. Prediction Model for Whanau Connections towards Cultural Satisfaction

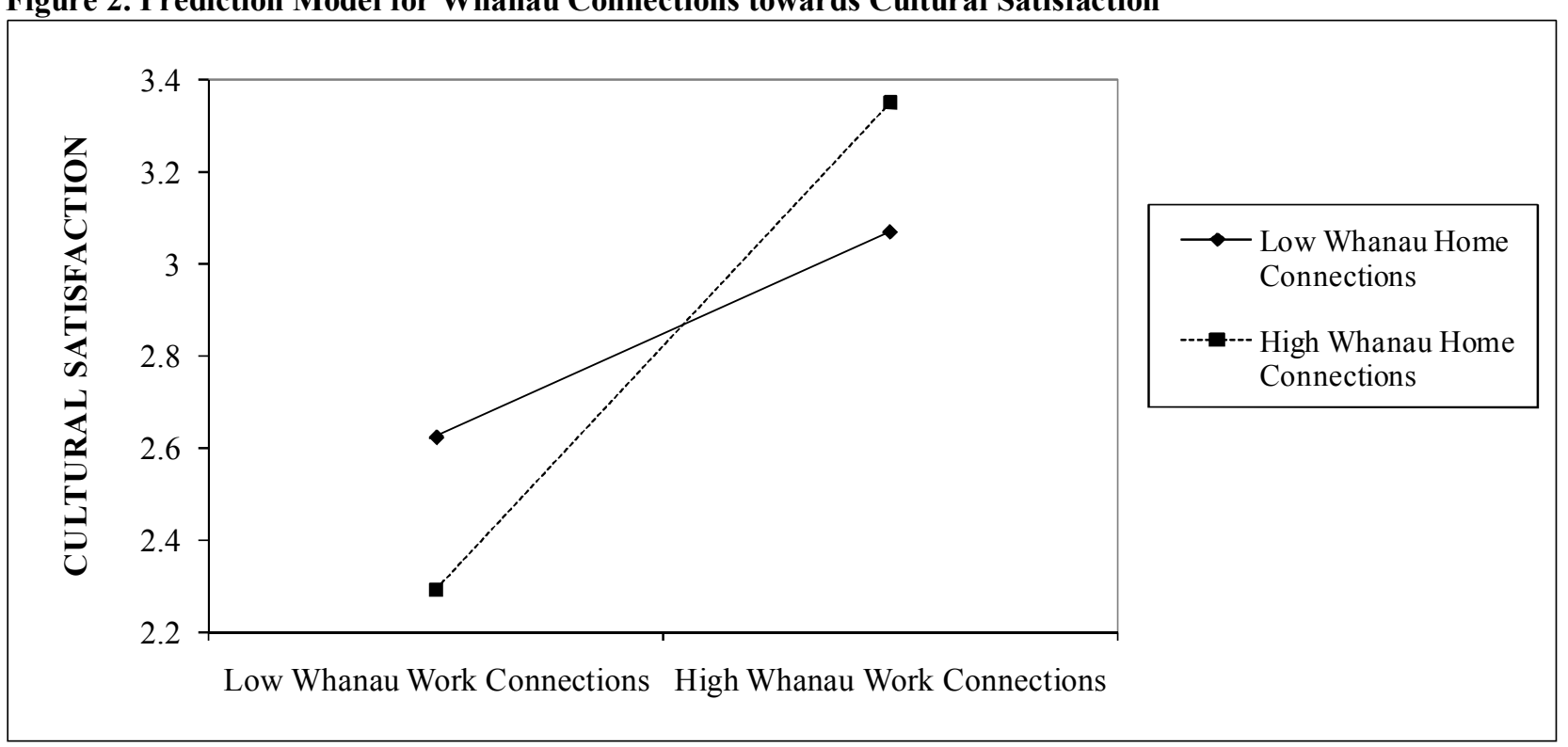

Labour, Employment and Work in New Zealand 2010 
Figure 3. Prediction Model for Whanau Connections towards Anxiety

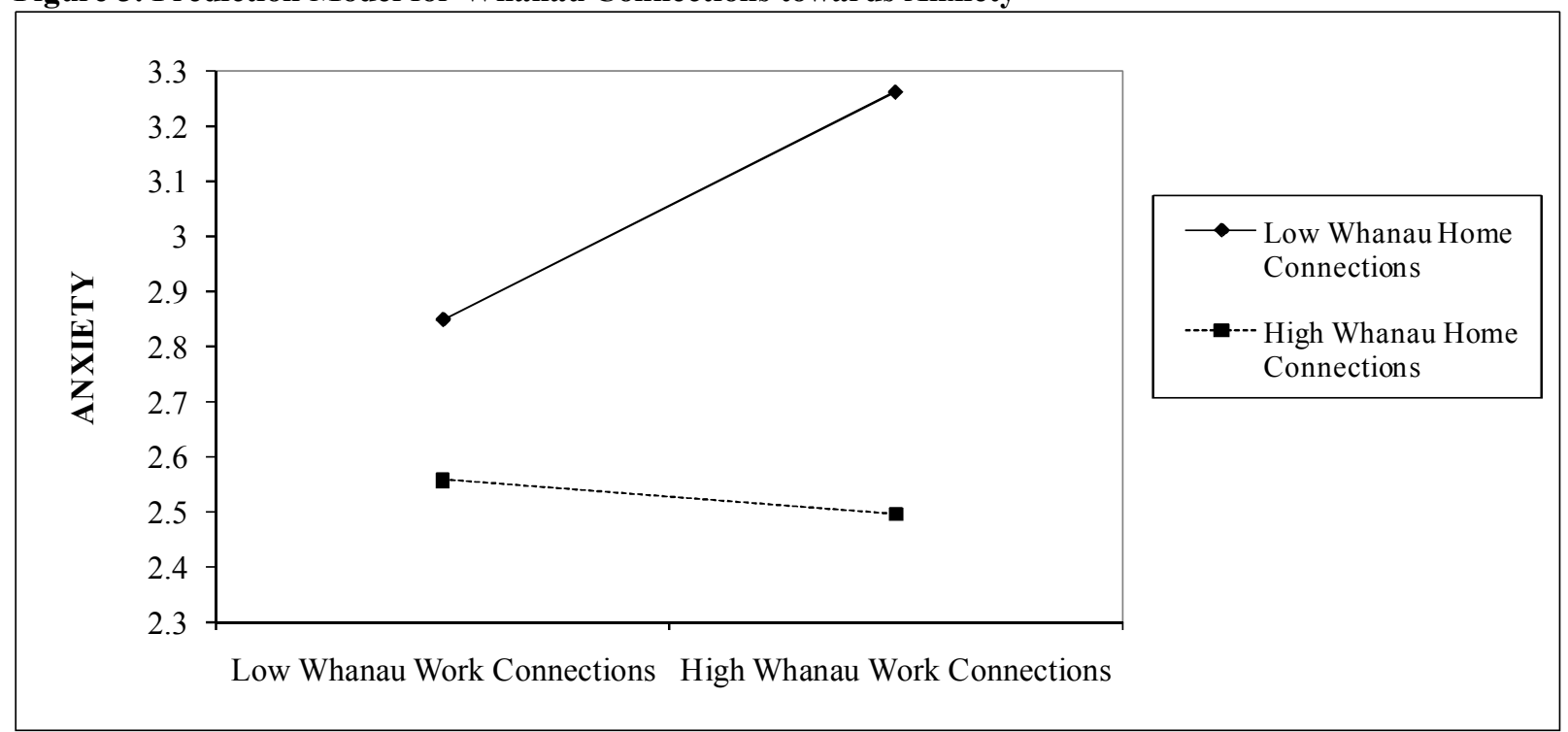

Figure 4. Prediction Model for Whanau Connections towards Depression

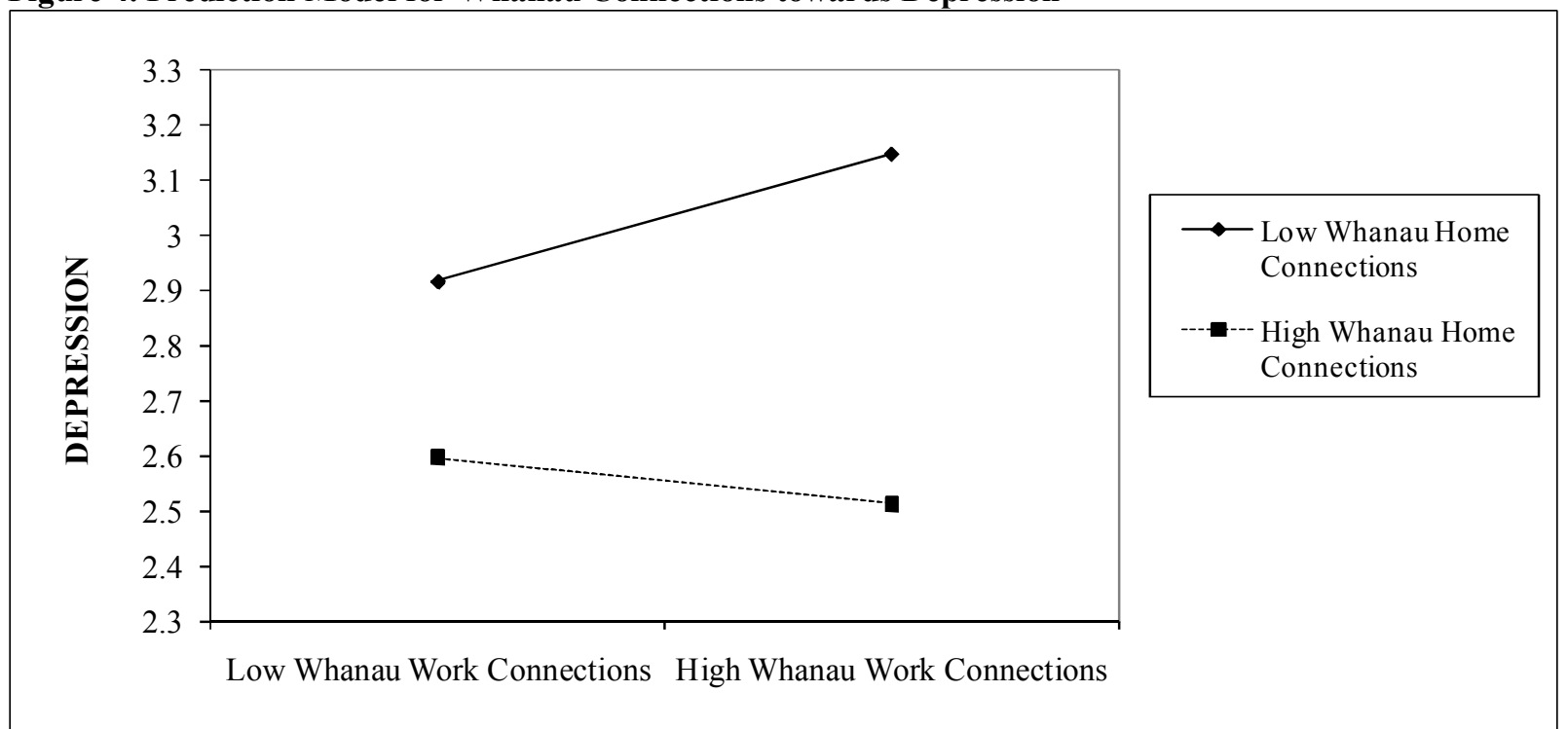

